\title{
Determining precolonial botanical foodways: Starch recovery and analysis, Long Island, The Bahamas
}

Andy J. Ciofalo ${ }^{1 *}$, William F. Keegan ${ }^{2}$, Michael P. Pateman ${ }^{3}$, Jaime R. Pagán-Jiménez ${ }^{1}$, and Corinne L. Hofman ${ }^{1}$

Caribbean Research Group, Faculty of Archaeology, Leiden University, Einsteinweg 2, 2333 CC Leiden, Netherlands

${ }^{2}$ Florida Museum of Natural History, P.O. Box 117800, University of Florida, Gainesville, FL 32611 keegan@flmnh.ufl.edu

3 Turks \& Caicos National Museum Foundation Grand Turk, Turks \& Caicos Islands Michael.Pateman@tcmuseum.org

*Corresponding author, a.j.ciofalo@arch.leidenuniv.nl Telephone number: +31616399408

Highlights

- Novel evidence of limestone microlith plant processing in the Caribbean.

- Tools associated with an earth oven, provided evidence for a previously unreported cooking technique in The Bahamas.

- Demonstration of how starch analysis provided information in tropical regions with poor botanical preservation.

\begin{abstract}
Descriptions of precolonial foodways in the Caribbean Islands have relied primarily on contactperiod European descriptions, which have been used to inform archaeological research. The use of ethnohistoric and indirect archaeological evidence is debated, and competing reconstructions of potential botanical foods and their cooking processes have resulted. To address this issue, starch analysis, which is suitable to provide information on human-plant interactions in tropical regions with poor botanical preservation, was carried out on samples from shell and limestone potential plant-processing tools from the Rolling Heads site, Long Island, The Bahamas. Results of this study revealed that some of these shell and lithic tools were used to process several different starchy food sources: maize (Zea mays L.), manioc (Manihot esculenta Crantz), and coontie (Zamia spp.). The presence of more than one plant species on both the microlith and shell tools, demonstrates their multi-purpose use. These novel data have also generated interpretations of plant processing with limestone grater chips. Overall, our research provides integral data regarding regional-specific processing of manioc, maize, and coontie. This report provides new
\end{abstract}


information regarding human-plant interactions in the Caribbean. Finally, this study provides data on the use of shell tools and lithic graters for processing plants it contributes to ongoing discussions of reconstructing ancient Bahamian and related Caribbean foodways.

Key words: starch analysis; foodways; Caribbean archaeology; microlith; shell tools; manioc

\section{Introduction}

Descriptions of precolonial foodways in the Caribbean Islands have relied primarily on contact-period European descriptions. The use of European accounts in conjunction with ethnographic data has been used to determine foodways predating these sources of information (Rouse, 1992). We adamantly believe this method of informing archaeological research should be heavily debated, and competing reconstructions of precolonial foodways have resulted. Interpretations of botanical foodways reported in the Spanish chronicles suggest that manioc (Manihot esculenta Crantz) and sweet potato (Ipomoea batatas (L.) Lam.) were the most important cultigens, while maize (Zea mays L.) was of limited importance (see Newsom and Wing, 2004, Pagán-Jiménez, 2013, Sauer, 1966). Despite numerous other botanical studies (Berman and Pearsall, 2008, Mickleburgh and Pagán-Jiménez, 2012, Pagán-Jiménez, 2007, Pagán-Jiménez, et al., 2015) microbotanical remains representing manioc's ubiquity has been statistically insignificant (less than 13\%) in the Caribbean archaeological record (Pagán-Jiménez, 2013, Pagán-Jiménez, et al., 2017). In contrast, maize, sweet potato, bean (Phaseolus spp.), and coontie (Zamia spp. ${ }^{1}$ have been found in numerous studies in the broader Caribbean region (Pagán-Jiménez, 2007, Pagán-Jiménez, 2009, Pagán-Jiménez and Oliver, 2008, Pagán-Jiménez, et al., 2015, Rodríguez Suárez and Pagán-Jiménez, 2008). Figueredo (2015) argues that maize was of greater dietary importance than manioc, whereas Newsom and Wing (2004:183) suggest coontie to be the primary consumed carbohydrate in The Bahamas. Veloz Maggiolo (1992), following Las Casas (1909), has also argued for the primacy of coontie, especially in the eastern Dominican Republic (Higüey Province). This study reports the first conclusive archaeological evidence for manioc and identified coontie in The Bahama Islands. Maize was identified in a previous study from The Bahamas (Berman and Pearsall, 2008), and is also recorded here.

Efforts to understand the diversity and use of botanical foods in the Caribbean has gained substantial attention in the last forty years (Fortuna, 1978, Keegan and DeNiro, 1988, Newsom, 1993, Newsom and Wing, 2004, Pagán-Jiménez, 2007), most recently through the extensive application of novel methods (Laffoon, et al., 2016, Mickleburgh and Pagán-Jiménez, 2012, Pagán-Jiménez, et al., 2015, Pestle and Laffoon, 2018). Starch grain analyses have consistently revealed the identification of cultivated, managed, and processed plants that were once believed not to preserve for archaeological recovery. These microbotanical remains have proven to be resistant to the dry, wet, and hot conditions that are typical in the tropics and may affect preservation.

In the tropics, because of copious amounts of rainfall and consistent high temperatures, organic remains decompose quickly in the humid soils (Babot, 1996). Thus, archaeobotanical research is difficult and can be problematic primarily due to poor preservation. In addition, the majority of tubers do not produce, or are purposely suppressed from producing pollen and

\footnotetext{
${ }^{1}$ Plants of the genus Zamia are known locally in The Bahamas as coontie and thus, the term coontie is used to denote plants of this genus in the rest of this article.
} 
produce few diagnostic phytoliths in the plant organs that are utilized for food (Torrence, 2006). Starch analysis also has the potential for recovering the most complete archaeobotanical record of many prominent economic plants in the precolonial Caribbean (Pagán-Jiménez, 2011). Starch analysis has the unique ability to show human interactions for creating and modifying plant-based foods and this microbotanical remain preserves exceptionally well in tropical conditions.

The new information gained from this study exposes some of the phytocultural (humanplant interactions) dynamics of the precolonial Bahamas. ${ }^{2}$ In 1492, the native peoples of The Bahamas were the first people encountered during the Spanish intrusions and were called Los Lucayos ("people of the small islands"), which has been anglicized as Lucayan. The earliest evidence for a human presence the Bahama archipelago is dated to around AD 700-800 (Berman, et al., 2013). It remains an open question of whether colonists arrived from Cuba, Hispaniola, or both (Keegan and Hofman, 2017). It is thought that the first migrants into The Bahamas belonged to the Ceramic Age ("Arawak") colonization of the Antilles, which originated in northeastern South America around 500 BC. There is, however, new evidence that their roots should be traced to the pre-Saladoid ("Ciboney") colonization of Cuba and that they practiced a horticultural economy (what Cuban archaeologists have called modo de vida protoagrícola) (Tabío and Rey, 1985, Veloz Maggiolo and Zanin, 1999). These differing conclusions have important implications concerning how botanical foodways in The Bahamas should be interpreted.

We begin with a discussion of the site from which the analyzed artifacts were recovered. Next, review the methods used, the taxonomic assessment of recovered starch grains, and the starch grains associated with the specific artifacts. We conclude with a discussion of the implications of botanical identifications for reconstructing socially learned practices of botanical food processing.

\subsection{Archaeological background-Rolling Heads Site (LN-101)}

Long Island was devastated by Hurricane Joaquin in late September 2015. In The Bahamas, eight hurricanes were reported between 1888 and 1960 causing the loss of life, houses, and crops (Mills, 2009:145-146). One hurricane every ten years was the average for The Bahamas (Doran Jr., 1955). Since 1960, an additional eight hurricanes have affected parts of The Bahamas, meaning hurricanes have increased to devastate this region at least once every seven years (Doran Jr., 1955, LeVin, 2017). Climate change and the ensuing increase of storms are a direct and immediate threat to the Caribbean islands, the people, and their archaeological sites. One impact of Hurricane Joaquin was the substantial scouring of the 6-meter-high sand dune that rises above north-facing Lowe's beach north of Clarence Town (Fig. 1). Local residents Nick Constantakis along with Nick and Anthony Maillus found two frontal-occipital modified Lucayan skulls on the beach, and identified two places where human bones were exposed in the dune face (designated site LN-101). In October 2016, Pateman and Keegan excavated three skeletons from this unusual dune burial, but no cultural materials were found in association with the burials. They returned to the burial site with a team of volunteers in December 2016 and 2017 to establish the cultural context of the burials. Ground-penetrating radar was used to remotely sense the burial area, and a systematic shovel test survey was conducted along the top of the dune within five meters of the

\footnotetext{
2 The Bahama archipelago designates a geographical area with two independent nations: The Commonwealth of the Bahamas and the Turks \& Caicos Islands. There are notable differences in the archaeology of these islands (Keegan 1997). Therefore, the current study focuses solely on The Bahamas.
} 
dune edge. No additional burials were encountered, but seven small activity areas were identified between Turtle Cove and Clarence Town (see Keegan and Mitchell, 1984 for a previous survey in this area). Artifact Kr1 came from a different site (LN-103; ST-16, 0-50 cmbs), which was found during shovel testing. LN-103 is east of LN-101, and about $800 \mathrm{~m}$ west of the main beach road in Clarence Town (Fig. 1).

One of these activity areas is located 60 meters east of burial \#1 (LN-101). It is possible that some of the site has eroded into the sea, but there were neither artifacts on the beach nor anthropogenic evidence on the dune face. One shovel test revealed a fairly dense cultural deposit, buried under $60 \mathrm{~cm}$ of sand. An L-shaped section of a $2 \times 2 \mathrm{~m}^{2}$ was excavated to obtain a broader exposure (Unit 2). The artifacts $(\mathrm{Kr} 2, \mathrm{Kr} 3, \mathrm{Kr} 4, \mathrm{Kr} 5, \mathrm{Kr} 6, \mathrm{Kr} 7$ and $\mathrm{Kr} 8$, Table 1) in this analysis are from Unit 2 (FS 17, 60-90 cmbs; and adjacent FS 43, 70-90 cmbs). In one corner of Unit 2, there was the outline of a pit with a concentration of fire-cracked rock, ash, and black soil that has been identified as the remains of an earth oven (Fig. 2).

Earth ovens are ethnographically known to be comprised of seven parts: prepared basin, fire, layer of hot rocks, lower packing layer, food, upper packing layer, and an earthen cap (Black and Thoms, 2014). Archaeological remains do not typically preserve all seven layers. Instead, the primary components that preserve would be the prepared basin, the fire leaves an ashy layer, followed by darker carbon-stained sediments. The earth oven reported here has all of the expected archaeological remains in addition to an absence of pottery but a close association with lithic plant processing tools that would assist with food preparation for an earth oven (van den Bel, et al., 2018).

The one AMS date from Unit 2 returned cal A.D. 1020-1060 (32.4\%) and A.D. 1075-1155 (63\%) from charcoal recovered at $70-90 \mathrm{cmbs}$ in Unit $2 .{ }^{3}$ Continued testing in the area revealed four similar activity areas separated by about $200 \mathrm{~m}$. All are of small size, and in addition to LN101, two other activity areas also had earth ovens (including EO\#3 at site LN-102, located on a low dune 500 m east of LN-101). A common characteristic of these activity areas was evidence for the manufacture of shell beads. A complete description of the excavation is being prepared (Keegan and Pateman, n.d.).

Table 1

Artifact provenance and contextual information of the analyzed samples.

\begin{tabular}{|l|l|l|}
\hline Provenance & Artifact raw material and type & Starch Lab Number \\
\hline LN-103 FS53 & Lithic "tool” & $\mathrm{Kr} 1$ \\
\hline LN-101 FS17 & Shell (Codakia orbicularis) scraper & $\mathrm{Kr} 2$ \\
\hline LN-101 FS17 & Shell (Codakia orbicularis) scraper & $\mathrm{Kr} 3$ \\
\hline LN-101 FS17 & Limestone tool & $\mathrm{Kr} 4$ \\
\hline LN-101 FS43 & Limestone micro flake & $\mathrm{Kr} 5$ \\
\hline LN-101 FS43 & Limestone micro flake & $\mathrm{Kr} 6$ \\
\hline LN-101 FS43 & Limestone micro flake & $\mathrm{Kr} 7$ \\
\hline LN-101 FS43 & Limestone micro flake & $\mathrm{Kr} 8$ \\
\hline
\end{tabular}

${ }^{3}$ Lab \# PSUAMS-1568, 960 +/- 20 BP, cal AD 2-sig (OxCal), percentages reflect probabilities (P). 


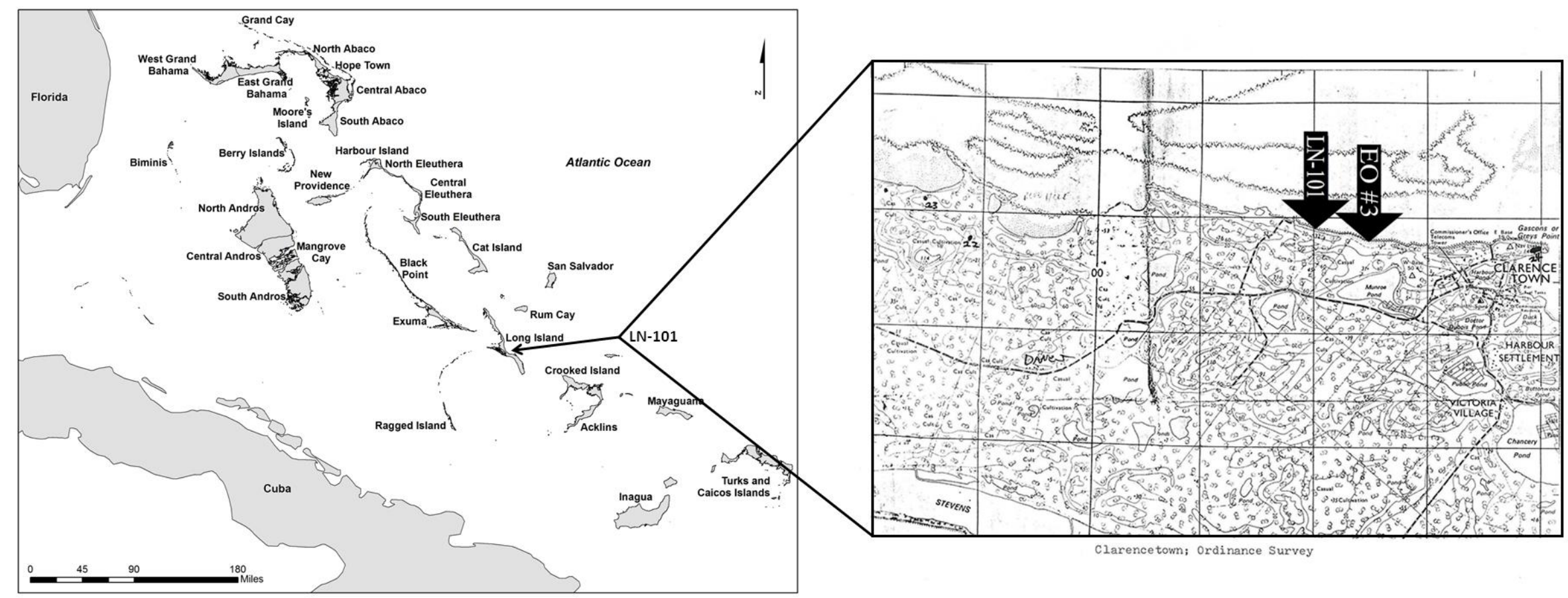

Fig. 1

Map of The Bahamas and Clarence Town marking archaeological site LN-101 and earth oven \#3 (EO\#3) 


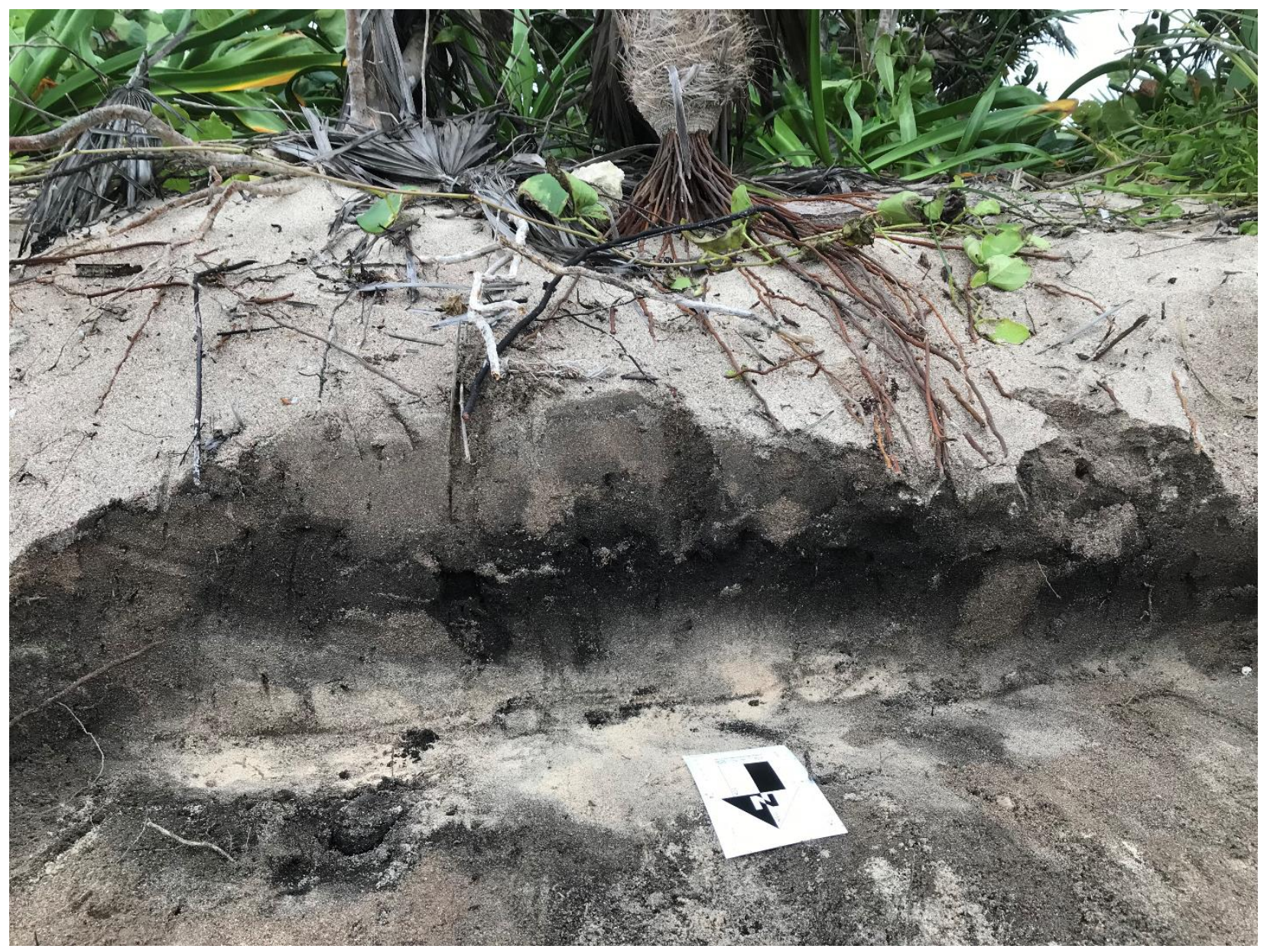

Fig. 2.

Archaeological remains of the earth oven \#3 (EO\#3)

\section{Methods}

The artifacts were selected based on Keegan's archaeological experience for inferring what could have possibly been plant-processing tools. The artifacts were hand bagged in the field and air dried on newspaper. None of the artifacts were washed or brushed. They were brought to the Caribbean Archaeology Laboratory at the Florida Museum of Natural History where they were again handled when measured, weighed, described, and photographed. The objects were then wrapped in aluminum foil, rebagged, and sent for analysis. Keegan sent these artifacts to the Faculty of Archaeology, Leiden University via Ciofalo. When the artifacts arrived at Leiden University, they were relabeled with the starch lab identifications of $\mathrm{Kr} 1, \mathrm{Kr} 2, \mathrm{Kr} 3, \mathrm{Kr} 4, \mathrm{Kr} 5$, Kr6, Kr7, and Kr8 (Table 1).

For this study, no peripheral sediment samples were investigated for starch content. The rationale regarding sampling soil surrounding an artifact would be that if residues found on artifacts are not apparent in the soil, then the starch grains found on artifacts are more likely a result from use of the artifact. However, it seems that starches found in soil surrounding an artifact are more related to transference from the artifact (Pagán-Jiménez, et al., 2015, Pearsall, et al., 2004). Consistently throughout experimental and archaeological studies, starch grain 
frequencies in sediment samples are considerably less than those recovered from artifact surfaces (Atchison and Fullagar, 1998, Barton, et al., 1998, Haslam, 2004, Loy, et al., 1992, Piperno, et al., 2009, Therin, 1998).

Admittedly, there is still a possibility for human caused airborne starch to contaminate artifacts both during excavation and laboratory procedures (Barton, et al., 1998, Crowther, et al., 2014, Dozier, 2016, García-Granero, et al., 2016, Hart, 2011, Laurence, et al., 2011, Loy and Barton, 2006, Mercader, et al., 2017, Mercader, et al., 2018). However, as the labs at the Faculty of Archaeology, Leiden University are being used for multiple studies of ancient microbotanical remains, they have been adequately fitted to prevent contamination. In addition, the negative results from this study seen in (Table 2) are a testament to the cleanliness of the laboratories and the security of the protocols followed to prevent post-excavation contamination. Regardless, the labs and consumables are consistently tested by different researchers working separately on starch research in the same facilities, with only one test with evidence of starch contamination. That test occurred more than a year prior to this analysis. During this routine contamination test on nitrile gloves from an unopened box a highly modified but unidentifiable starch grain was discovered. While the gloves claim to be 'powder-free', they are only made with less starch powder than other gloves that are not labeled as powder-free (Laurence, et al., 2011, Loy and Barton, 2006, Messner, 2011:60). Because of this discovery, the choice to not to wear gloves, instead washing hands thoroughly before any laboratory procedures has been made.

After photographing each artifact they were lightly washed with purified water, which helped remove possible modern contamination and other matrix or lightly adhering residues that were never a part of the artifacts ancient use history (Barton and Torrence, 2015). The entire surface of each artifact was sampled separately using an ultrasonic bath (procedure adapted from Pagán-Jiménez, 2007, Pearsall, et al., 2004, Perry, 2004). For this extraction, the artifacts sat in ultra-purified water in new plastic cups undisturbed for a period of twenty minutes to "soak". The sonicator was then run for a period of five minutes. As the artifacts were removed from the containers, they were rinsed with ultra-purified water drained into the containers with the contents successively poured into new $50 \mathrm{ml}$ sterile plastic tubes. The tubes were centrifuged at $4000 \mathrm{rpm}$ for six minutes. The supernatant (liquid lying above solid residue) was decanted and samples were left to dry in a controlled environment. All of the residue-sediment samples were processed for the separation of starch grains with Cesium Chloride $(\mathrm{CsCl})$, as discussed subsequently.

The objective for this part of the protocol was to separate the starch grains through flotation and isolate them from other particles. The following protocol was applied to this study after Pagán-Jiménez (2007), (modified from Atchison and Fullagar, 1998, Barton, et al., 1998, PagánJiménez, et al., 2015, Pearsall, et al., 2004). Once the samples were completely dried a heavyliquid solution of $\mathrm{CsCl}$ and ultra-purified water, prepared to $1.80 \mathrm{~g} / \mathrm{cm}^{3}$ density was added. The solution and samples were agitated and mixed using an ultrasonic bath for at least one minute, then vortexed for 30 seconds. Next, samples were centrifuged at $2500 \mathrm{rpm}$ for five minutes. The supernatant was decanted into new sterile micro-centrifuge $1.5 \mathrm{ml}$ plastic tubes. Density separation isolates starch grains from other particles due to starches having an average specific gravity of $1.5 \mathrm{~g} / \mathrm{cm}^{3}$ (Pagán-Jiménez, 2011).

In an effort to obtain a clean microscope slide, so microscopic observation was easier and starches were not obscured by other birefringent matter, all $1.5 \mathrm{ml}$ plastic tubes with the remaining supernatant from the previous steps had $\mathrm{CsCl}$ added until the tubes were filled. These tubes were centrifuged at $2500 \mathrm{rpm}$ for five minutes, and the supernatant was decanted into new micro-centrifuge $1.5 \mathrm{ml}$ tubes. Following, ultra-purified water was added to fill the tubes, and the 
tubes were manually agitated to initiate a rinsing procedure. Next, the tubes were centrifuged for eight minutes at 9,000 rpm in a microcentrifuge. To reduce the $\mathrm{CsCl}$ solution's specific gravity, the supernatant was decanted and replaced with ultra-purified water, which dilutes the mixture. The next two rinses are the same, except for the time run in the microcentrifuge was decreased from eight to five minutes. The remaining residues were slide-mounted in a small drop of glycerin. The microscope slides were covered with coverslips but not sealed. All slides were stored horizontally in new cardboard microscope slide holders for the subsequent microscopic observations.

\subsection{Taxonomic ascription of the recovered starch grains}

Studied microbotanical remains such as phytoliths, spores, and pollen are naturally dispersed in large quantities throughout the environment without human intervention; in contrast, starches are typically released from plant organs through human caused processes or in limited cases by decomposition (Beck and Torrence, 2006, Ma, et al., 2017, Pagán-Jiménez, 2007). Thus, the relation between artifacts, human behaviors, and plant use appear to have a strong correlation seen best through starch analysis (Holst, et al., 2007, Pagán-Jiménez, 2009, Pearsall, et al., 2004, Perry, 2004).

At present, we have assembled a comparative reference collection of starch grains obtained from recent economically useful and edible plants with the majority collected and processed by Pagán-Jiménez with some samples obtained from CIMMYT’s Maize Genetic Resources (PagánJiménez, 2007, Pagán-Jiménez, 2015a). Other samples were obtained from the Economic Botany collection of Naturalis Biodiversity Center Leiden, the Netherlands, the Montgomery Botanical Center Coral Gables, Florida, and from specimens that are endemic to or locally grown in the Bahamas collected and processed by Ciofalo. In sum, the reference collection contains modern starches from more than 140 specimens representing 70 genera and 63 wild, domesticated, and cultivated species from the Antilles, continental tropical Americas (mainly the continental circum-Caribbean area), The Bahamas, and parts of the Old World, in order to assist in identifying taxa. Descriptive analysis of modern samples with detailed explanations of morphometric features allows for the identifications of ancient starches through comparison (e.g., Pearsall, et al., 2004, Perry, et al., 2007, Piperno and Holst, 1998). For this study, if the majority of these observed diagnostic characteristics of the ancient starches are not seen in the modern reference collection, then the taxonomic identification is tentative at best. In these cases, the use of categories "cf." (in reference to the closest tentative classification) and "not identified" was employed. A reliable or secure identification was not established if archaeological starch grains exhibit traits that are not documented in our reference collection or in consulted published sources (Berman and Pearsall, 2008, Dickau, 2005, Pagán-Jiménez, 2007, Pagán-Jiménez, 2015a, Perry, 2004, Piperno and Holst, 1998, Reichert, 1913). In this research there was also a focus during the identification process regarding plant processing techniques based upon published starch grain experimental studies (Babot, 2003, Babot, 2006, Henry, et al., 2009, Mickleburgh and Pagán-Jiménez, 2012, Pagán-Jiménez, 2015b, Pagán-Jiménez, et al., 2017), which were aimed to document different damaging factors and their visual effects on starch grains. Human caused manipulation of starchy plants and the associated damages and morphometric changes observed in both ancient starches and modern experimental samples can be correlated with these specific processes. Thus, secure and tentative identifications of starches in this study are based on diagnostic and/or distinctive features described elsewhere. Specific morphometric features used were shape, size, presence, and location of the hilum within the starches; as well as presence and 
appearance of fissures, presence and types of pressure facets, presence and appearance of lamellae, and in some cases the appearance and projection of extinction crosses (Pagán-Jiménez, et al., 2016).

For measurements and observations, starches were photographed using a Leica DM2700 P polarizing light microscope. The primary indicative element, but not an exclusive component to discern starch gains from other residues, is the presence of the distinctive extinction cross which is observable under polarized light. All the starch grains recovered were photographed in multiple positions (when possible) by rotation and with different focal lengths. After the initial analysis, the slides were stored horizontally in new cardboard microscope slide holders for future observation and preservation. Additionally, the original sample collection tubes with remaining residues were filled with ultra-purified water, capped, and set aside in case further starch extraction was considered useful or a future phytolith study.

\section{Results}

Four artifacts $\mathrm{Kr} 2, \mathrm{Kr} 3, \mathrm{Kr} 4$, and $\mathrm{Kr} 7$ were processed with recovered starches. In addition, another four artifacts $\mathrm{Kr} 1, \mathrm{Kr} 5, \mathrm{Kr} 6$, and $\mathrm{Kr} 8$ were also sampled but there was no evidence of starch recovered from these four artifacts. Table 2 synthesizes the results attained from studying the starches recovered from these artifacts. This synthesis of associated results allows for further meaningful interpretations that will be integrated into a broader site analysis.

Table 2

Distribution of recovered starches by sample and their plant sources.

${ }^{a}$ Ubiquity refers to the occurrence of identified taxa amongst the entire artifact sample spectra. It was calculated by dividing the presence of securely identified taxa by the total number of analyzed artifacts. 'Minimum species richness combines both tentative ("cf.") and secure identifications. This excludes starches that were not identified because they could have been produced by some of the already identified taxa.

\begin{tabular}{|c|c|c|c|c|c|c|c|c|c|c|}
\hline Provenance & $\begin{array}{c}\text { LN- } \\
103 \\
\text { FS53 }\end{array}$ & $\begin{array}{c}\text { LN- } \\
101 \\
\text { FS17 }\end{array}$ & $\begin{array}{c}\text { LN- } \\
101 \\
\text { FS17 }\end{array}$ & $\begin{array}{c}\text { LN- } \\
101 \\
\text { FS17 }\end{array}$ & $\begin{array}{c}\text { LN- } \\
101 \\
\text { FS43 }\end{array}$ & $\begin{array}{c}\text { LN- } \\
101 \\
\text { FS43 }\end{array}$ & $\begin{array}{c}\text { LN- } \\
101 \\
\text { FS43 }\end{array}$ & $\begin{array}{c}\text { LN- } \\
101 \\
\text { FS43 }\end{array}$ & & \\
\hline $\begin{array}{c}\text { Starch Lab } \\
\text { Sample ID }\end{array}$ & $\mathrm{Kr} 1$ & $\mathrm{Kr} 2$ & Kr3 & $\mathrm{Kr} 4$ & $\mathrm{Kr} 5$ & Kr6 & Kr7 & Kr8 & & \\
\hline $\begin{array}{l}\text { Artifact } \\
\text { material }\end{array}$ & Limestone & Shell & Shell & Limestone & Limestone & Limestone & Limestone & Limestone & & \\
\hline Taxa & & & & & & & & & $\begin{array}{c}\text { Starch } \\
\text { count }\end{array}$ & $\begin{array}{c}\text { Ubiquity } \\
(\%)^{\mathrm{a}}\end{array}$ \\
\hline $\begin{array}{r}\text { Manihot } \\
\text { esculenta } \\
\text { Crantz }\end{array}$ & & & 32 & & & & 11 & & 43 & 25 \\
\hline $\begin{array}{r}\text { cf. Manihot } \\
\text { esculenta } \\
\text { Crantz }\end{array}$ & & & 6 & & & & 2 & & 8 & 25 \\
\hline Zamia spp. & & & 1 & & & & & & 1 & 12.5 \\
\hline Zea mays L. & & 2 & & & & & 6 & & 8 & 25 \\
\hline $\begin{array}{c}\text { cf. Zea } \\
\text { mays L. }\end{array}$ & & 3 & & & & & 6 & & 9 & 25 \\
\hline $\begin{array}{r}\text { Not } \\
\text { identified }\end{array}$ & & 0 & 9 & 1 & & & 4 & & 14 & -- \\
\hline
\end{tabular}




\begin{tabular}{|r|l|l|l|l|l|l|l|l|l|l|}
\hline $\begin{array}{r}\text { Starch } \\
\text { count }\end{array}$ & 0 & 5 & 48 & 1 & 0 & 0 & 29 & 0 & -- & \\
\hline $\begin{array}{r}\text { Minimum } \\
\text { species } \\
\text { richness }^{\mathrm{b}}\end{array}$ & & 1 & 2 & & & & 2 & & -- & \\
\hline
\end{tabular}

3.1 Artifact $\mathrm{Kr} 2$

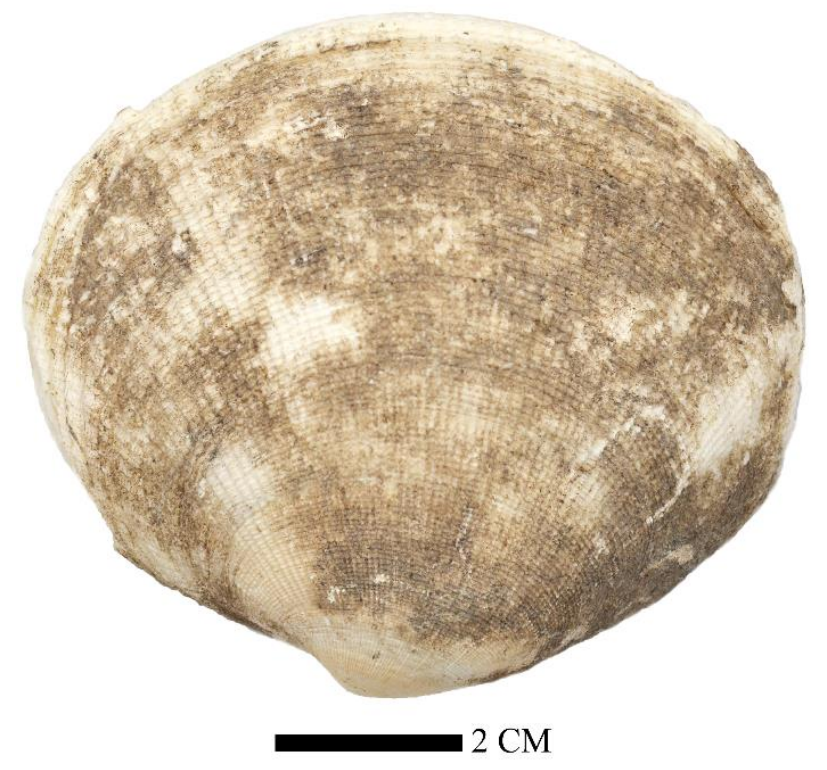

Fig. 3.

Codakia orbicularis plant processing tool (artifact $\mathrm{Kr} 2$ ).

This artifact is a shell (Codakia orbicularis) scraper that has macroscopically observed use-wear along the lip manifested in a broken and beveled edge (Fig. 3). This shell is approximately eight $\mathrm{cm}$ wide. Of the five starch grains recovered from this tool, two have been securely identified as maize (Zea mays L.) (Fig. 4 a,a1,d), on the basis of diagnostic continuous double borders, maximum size measurements of $21.96 \mu \mathrm{m}$ and $19.4 \mu \mathrm{m}$ respectively, and polygonal shapes according to our reference collection and other published sources (Holst, et al., 2007, Mickleburgh and Pagán-Jiménez, 2012, Pagán-Jiménez, 2007, Pagán-Jiménez, 2015a, Pagán-Jiménez, et al., 2015, Pearsall, et al., 2004). Two of the three starch grains tentatively identified as maize (Fig. 4b,c) have evidence of pressure (scraping/cutting) probably generated by use of this shell. Of special note for interpretations is the starch grain in (Fig. 4a, a1), because there is evidence for the beginning of a fold. This fold could have been caused from heating a maize cob/peduncle with low heat in a humid, but not boiling cooking environment, maybe to ease manipulation with this tool. Codakia shells are obtained easily along Caribbean coasts, and there is no indication they contributed to a significant part of the indigenous diet, instead they were likely considered useful for multifunctional tools (Van Gijn, et al., 2008). 

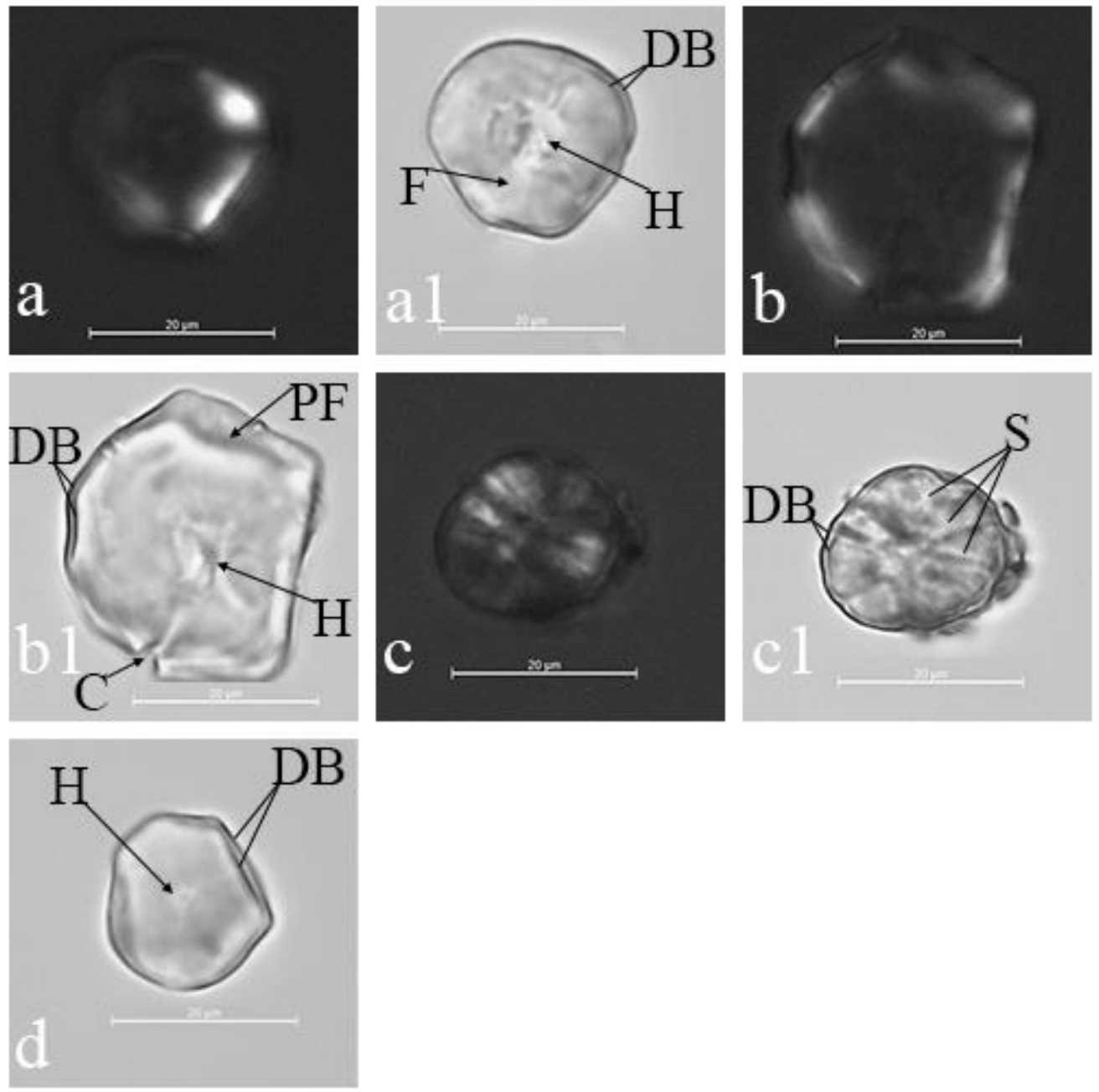

Fig. 4.

Starches recovered from artifact $\mathrm{Kr} 2$

(a) Maize starch with polarizing filter and dark field view, notice partial optical loss of birefringence. (a1) The same maize starch with bright field view. (b) cf. maize starch with polarizing filter and dark field view, notice partial optical loss of birefringence. (b1) The same cf. maize starch with bright field view. (c) cf. maize starch with polarizing filter and dark field view, notice partial optical loss of birefringence. (c1) The same cf. maize starch with bright field view. (d) Maize starch with bright field view. Figure legend: "C" crack; "DB" double border; "F" fold; "H" hilum; "PF" pressure facet; "S" striation. 


\subsection{Artifact $\mathrm{Kr} 3$}

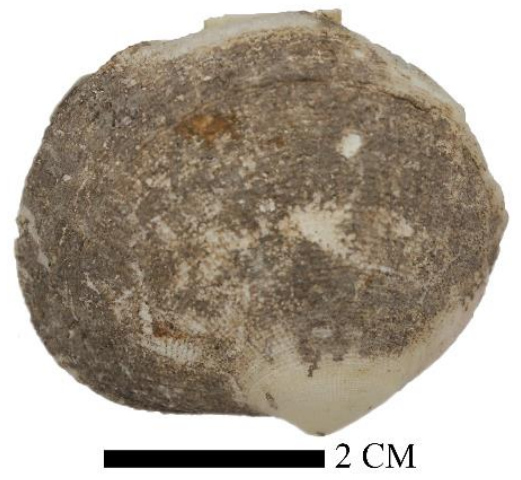

Fig. 5.

Codakia orbicularis plant processing "tool” (artifact Kr3).

This artifact is a shell scraper (Codakia orbicularis) that has macroscopically observed signs of use-wear along the lip manifested in a beveled and broken edge. This artifact is notably smaller than artifact $\mathrm{Kr}$ 2, with a longest measurement of approximately three and a half centimeters. At least two potentially poisonous taxa are represented in the 48 recovered starches from this tool, which evidently processed multiple starchy-food sources. Of the 48 starches, 32 have been securely identified as manioc, one as coontie, six tentatively ascribed as manioc, and nine with no identifications (many were too regular, meaning common in many species, or with not enough diagnostic features to identify) (Table 2). The majority of identified manioc starch grains are bell shaped, with lineal or stellate fissures, have two to five pressure facets, and all range in measurements between 7.91-21.39 $\mu \mathrm{m}$, all of these characteristics match our reference collection and previously published sources (Pagán-Jiménez, 2015a, Perry, 2002b, Piperno, 2006). It would have been beneficial to carry out a use-wear analysis, especially on the bivalve tools because based upon experimental studies manioc is known to create a unique polish topography when microscopically observed (Lammers-Keijsers, 2007:56).

Of the nine with no identification, the starch shown in Fig. 6a is worthy of note because there is evidence of the beginning of fermentation, with the starch grain being partially affected by enzyme degradation. Another starch grain shown in Fig. $6 \mathrm{~b}$ has been securely identified as manioc, which also has surface damage from enzymatic activity (Pagán-Jiménez, 2015b). With only two of 48 starch grains with signs of enzymatic activity it is unlikely soil bacteria (postdepositional activity) led to these alterations. Alternatively, the 46 starches without signs of enzyme degradation may just have been more naturally resistant to bacterial digestion (Hutschenreuther, et al., 2017). The starches in (Fig. 6b-1) are some of the exemplified manioc starch grains recovered from this shell tool.

The starch grain in Fig. $6 \mathrm{~m}$ has been securely identified as coontie because it was consistent with our reference collection with the size $(30.13 \mu \mathrm{m})$, shape (truncated and lenticular, when rotated), lamellae (faint undulating), and extinction cross arm shape (curved x shape). For comparison, our reference collection contains a few different species of coontie and a particularly relevant sample of Zamia lucayana B. (see more on this species in section 4. Discussion). Because we are unsure, which species of coontie has been identified in this study, we wish to 
report the size ranges for multiple species of coontie from our reference collection (Table 3 ). In addition, since Berman and Pearsall (2000) state that size is one of the defining differences between coontie and yautia (Xanthosoma sp.) it is useful to report size measurements for our sample of yautia (Table 3). Thus, the identified coontie starch in this study is almost double the length of the largest yautia sample measurement from our collection, and in conjunction with the other previously described characteristics; it has been securely identified to the level of coontie's genus- Zamia.

Table 3

Our reference collection of coontie and yautia starch grain measurements, medians, and standard deviations.

\begin{tabular}{|c|c|c|c|c|c|}
\hline Species & Provenance & Sample size & $\begin{array}{c}\text { Size range } \\
(\mu \mathrm{m})\end{array}$ & $\begin{array}{c}\text { Median } \\
(\mu \mathrm{m})\end{array}$ & $\begin{array}{c}\text { SD. } \\
(\mu \mathrm{m})\end{array}$ \\
\hline $\begin{array}{c}\text { Zamia lucayana } \\
\text { B. }\end{array}$ & $\begin{array}{c}\text { Montgomery } \\
\text { Botanical Center } \\
\text { Coral Gables, } \\
\text { Miami, Florida }\end{array}$ & 104 & $9.4-61.7$ & 33.9 & \pm 13.28 \\
\hline Zamia pumila L & $\begin{array}{c}\text { San Juan Puerto } \\
\text { Rico }\end{array}$ & 138 & $5.72-49.4$ & 15.29 & \pm 7.03 \\
\hline $\begin{array}{c}\text { Xanthosoma } \\
\text { sagittifolium L. } \\
\text { Schott. }\end{array}$ & $\begin{array}{c}\text { San Juan Puerto } \\
\text { Rico }\end{array}$ & 83 & $3.1-15.61$ & 10.24 & \pm 2.95 \\
\hline \multicolumn{2}{|l}{} & & & & \\
\hline
\end{tabular}



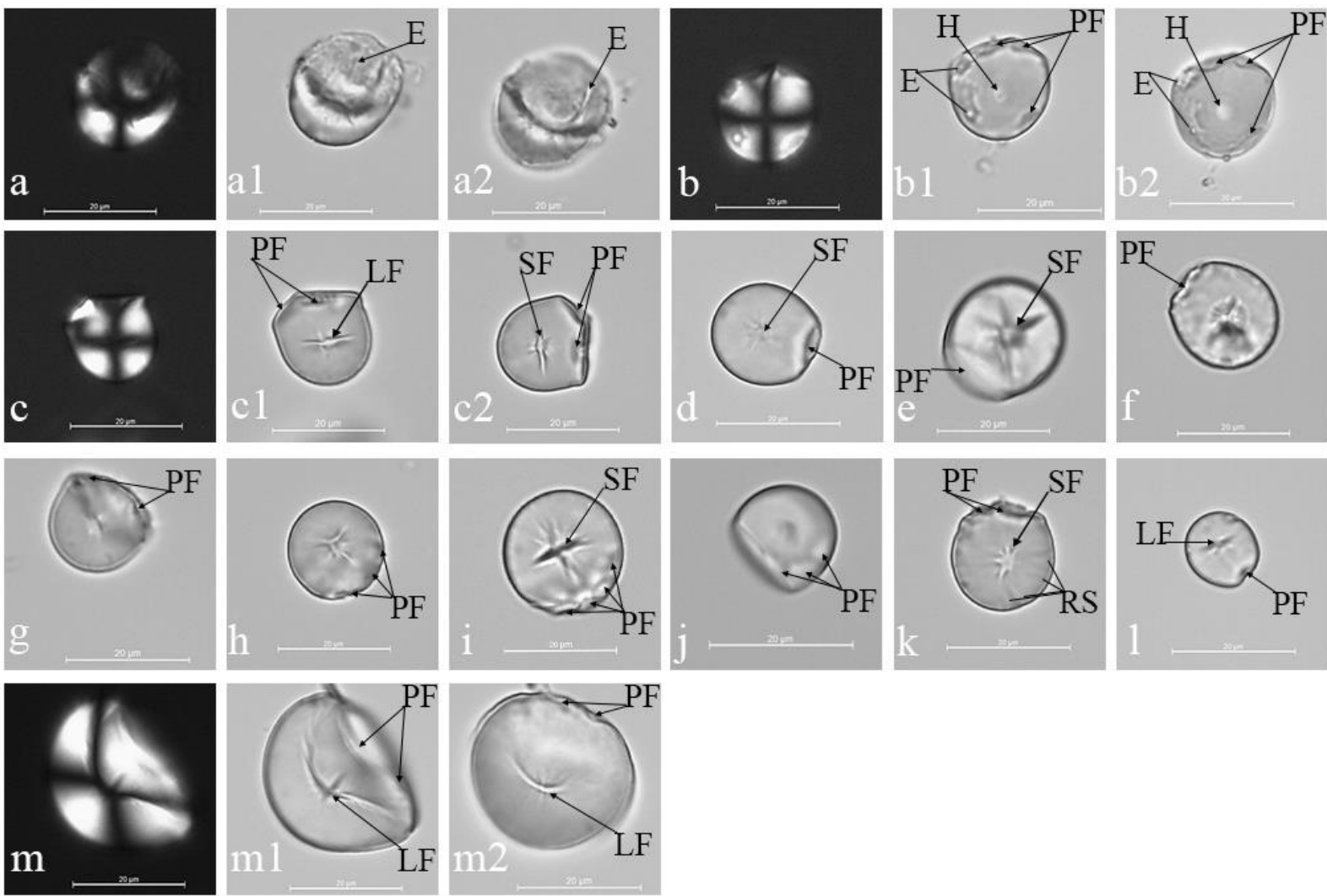

Fig. 6

Starches recovered from artifact $\mathrm{Kr} 3$

(a) Unidentified starch with polarizing filter and dark field view, notice partial optical loss of birefringence. (a1) The same unidentified starch with bright field view. (a2) The same unidentified starch at a different focal length with bright field view. (b) Manioc starch with polarizing filter and dark field view. (b1) The same manioc starch with bright field view. (b2) The same manioc starch at a different focal length with bright field view exposing the enzymatic damage. (c) A different manioc starch with polarizing filter and dark field view. (c1) The same manioc starch with bright field view. (c2) The same manioc starch with bright field view rotated exposing diagnostic features. (d-l) Other securely identified manioc starch grains with bright field view. (m) Coontie starch with polarizing filter and dark field view. (m1) The same coontie starch with bright field view. (m2) The same coontie starch rotated exposing a diagnostic shape. Figure legend: "E" enzyme degradation; "H" hilum; "LF" lineal fissure; "PF" pressure facet; "RS" radial striation; "SF" stellate fissure.

It is less probable that all of the manioc starches recovered from this artifact originated from the same tuber. However, it is likely that they represent manioc grown during the use-history of the artifact, which is a circumscribed snapshot of manioc cultivation. It is not often this many ancient manioc starches have been securely identified on one artifact. We hope that reporting the size measurements for ancient manioc starches will help future researchers identify manioc starches in their own samples. This also adds to the mounting evidence that smaller starches do not survive taphonomic processes as often as resistant starches. Thus, of the 32 starch grains securely identified as manioc from our study in comparison with measurements from other research summarized in (Table 4) the following conclusions can be made. All the reported measurement ranges of modern manioc have recorded smallest length measurements of less than $1.21 \mu \mathrm{m}$ compared to the ancient starch measurements from this study. In addition, four out of five of the modern manioc reference collections have median, mean, or common size measurements smaller 
than the median measurements for the ancient starch grains, both in this study and the average reported by Ugent, et al. (1986). The combined information provides evidence suggesting that ancient immature and thus smaller starches do not survive taphonomic processes as often as mature and larger (resistant) starches. This idea is similar to how some species are naturally more resistant to enzyme digestion (Hutschenreuther, et al., 2017), and may be similar to how some resistant starches survive the human digestive process better than others (Pereira and Leonel, 2014). As Piperno (2006:58) states, "size alone does not universally separate wild from domesticated Manihot". In addition, the evidence from our findings could also refute the idea that starch grains from cultivated plants became larger over time compared to the species ancestors (e.g., Perry, 2002b, Perry, et al., 2007). However, many factors can influence the size of manioc starches including cultivation practices, tuber size, and soil fertility (Perry, 2002b).

Table 4

Collection of manioc starch grain measurements, medians, and standard deviations.

\begin{tabular}{|c|c|c|c|c|c|c|}
\hline Source & Provenance & $\begin{array}{c}\text { Variety } \\
\text { (bitter or } \\
\text { sweet) }\end{array}$ & Sample size & $\begin{array}{l}\text { Size range } \\
(\mu \mathrm{m})\end{array}$ & $\begin{array}{l}\text { Median } \\
(\mu \mathrm{m})\end{array}$ & $\begin{array}{l}\text { SD. } \\
(\mu \mathrm{m})\end{array}$ \\
\hline This study & $\begin{array}{l}\text { Rolling Heads } \\
\text { LN-101, } \\
\text { archaeological }\end{array}$ & ? & 32 & $7.91-21.39$ & 16.42 & \pm 3.4 \\
\hline $\begin{array}{c}\text { Ugent, et al. } \\
\text { (1986) }\end{array}$ & $\begin{array}{l}\text { Casma Valley, } \\
\text { Peru } \\
\text { archaeological }\end{array}$ & ? & ? & $5-35$ & 20 (average) & $?$ \\
\hline $\begin{array}{l}\text { Ciofalo's } \\
\text { reference } \\
\text { collection }\end{array}$ & $\begin{array}{c}\text { Providenciales, } \\
\text { TCI } \\
\text { street market } \\
\text { grown on North } \\
\text { Caicos } \\
\end{array}$ & Sweet & 108 & $3.1-20.7$ & 10.55 & \pm 3.362 \\
\hline $\begin{array}{l}\text { Pagán- } \\
\text { Jiménez } \\
(2007)\end{array}$ & $\begin{array}{l}\text { Aibonito, Puerto } \\
\text { Rico, farm, } \\
\text { locally produced }\end{array}$ & Sweet & 126 & $5-20$ & 13.05 & \pm 3.784 \\
\hline $\begin{array}{l}\text { Pagán- } \\
\text { Jiménez } \\
\text { (2015a) }\end{array}$ & $\begin{array}{l}\text { Quito, Ecuador, } \\
\text { street market }\end{array}$ & Sweet & 20 & $6.7-37.3$ & 17.16 & \pm 7.96 \\
\hline $\begin{array}{l}\text { Piperno } \\
(2006)\end{array}$ & $?$ & $?$ & $?$ & $6-28$ & 13-16 (mean) & $?$ \\
\hline $\begin{array}{l}\text { Reichert } \\
\text { (1913) }\end{array}$ & $?$ & Sweet & ? & $5-20$ & $\begin{array}{l}15 \text { (common } \\
\text { size) }\end{array}$ & ? \\
\hline
\end{tabular}

\subsection{Artifact $\mathrm{Kr} 4$}


This artifact (Fig. 7) is a limestone tool that could be classified as a "blade" based on morphology. The macro use-wear patterns seem to indicate the sharp edges were used. However, as the entire artifact was sampled all at once it is impossible to determine the exact micro-context of the recovered starch grain.

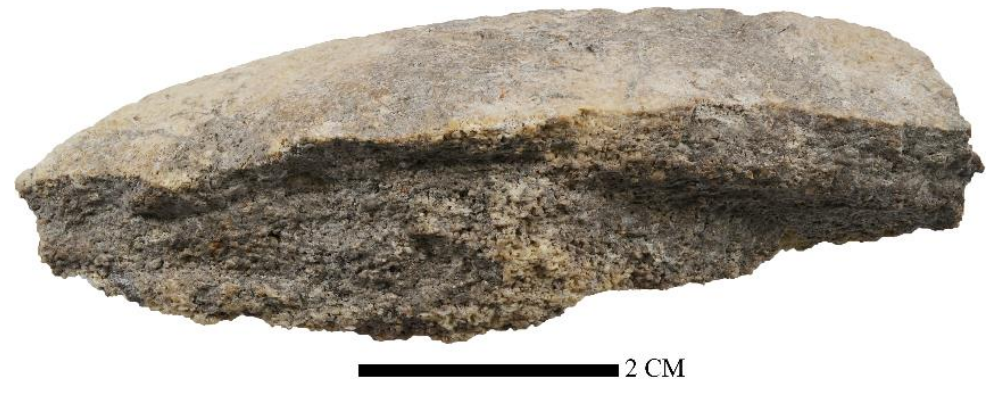

Fig. 7

Limestone "tool" (Artifact Kr4).

The one starch grain recovered from this artifact was severely altered by processing (Fig. 8). The extinction cross experienced an optical loss of birefringence, the surface of the starch grain is bumpy, which indicate pressure (grinding/grating/cutting) probably from use of this tool (Babot, 2003, Mickleburgh and Pagán-Jiménez, 2012). In addition, there is a bright ring around the hilum, which is a damage pattern only observed on maize starch grains after the plant has been intensely ground(Mickleburgh and Pagán-Jiménez, 2012). However, because there were not enough diagnostic characteristics observable on the starch and only one starch was recovered this starch cannot be identified nor can the "tool" be determined to be a plant-processing implement.
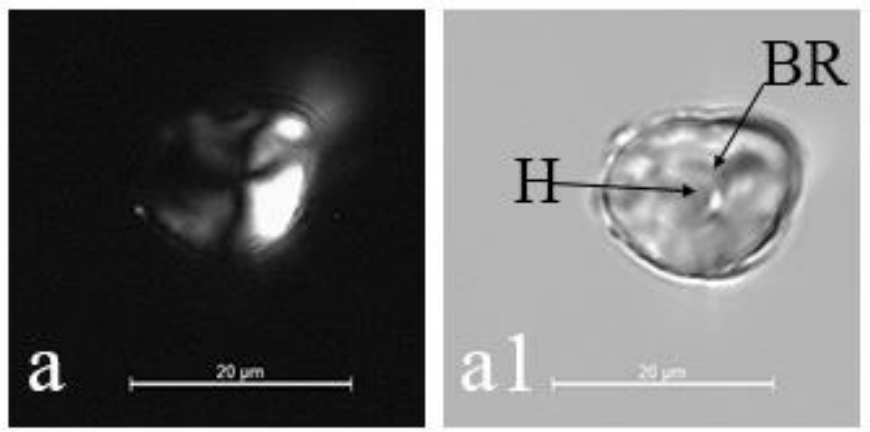

Fig. 8

Starch recovered from artifact $\mathrm{Kr} 4$

(a) Unidentified starch with polarizing filter and dark field view, notice the partial loss of extinction cross.

(a1) The same unidentified starch with bright field view, notice the bumpy surface.

Figure legend: "BR" bright ring; "H" hilum; 


\subsection{Artifact $\mathrm{Kr} 7$}

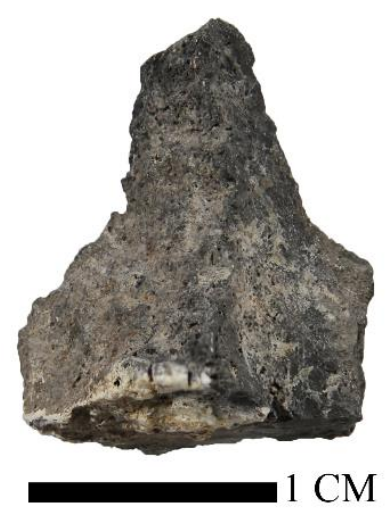

Fig. 9

Limestone grater chip (artifact Kr7).

This artifact (Fig. 9) is a limestone microlith. It is plausible that the microlith examined in this study is a grater chip that was entrenched in a wooden board. This artifact is larger but morphologically similar to some of the chert microliths analyzed by Berman and Pearsall (2008), and to the ethnographic grater flakes examined by Walker, et al. (1989). There were 29 starches recovered from this tool. Eleven of the starch grains have been securely identified as originating from manioc (Table 2). Three of those 11 manioc starch grains have some particles on and near the surfaces of the grains (example Fig. 10g) indicating that the plant organ was heated in a dry cooking environment (sensu Henry, et al., 2009). Of particular interest for further interpretations is one of the unidentified starch grains (shown in Fig. 10a,a1,a2), which has evidence of pits in the surface of the grain likely caused by enzymatic degradation. There are also six confirmed maize starch grains and six tentatively identified maize starch grains (Fig. 10b-f). Seven of these 12 maize starch grains have evidence of pressure (grating/grinding/cutting) damage. In sum, 17 of the 29 starches have damage patterns due to pressure. We infer that the damage patterns were manifested from a degree of pressure being applied to the plant organs because of the use of this tool or the larger grater board. 

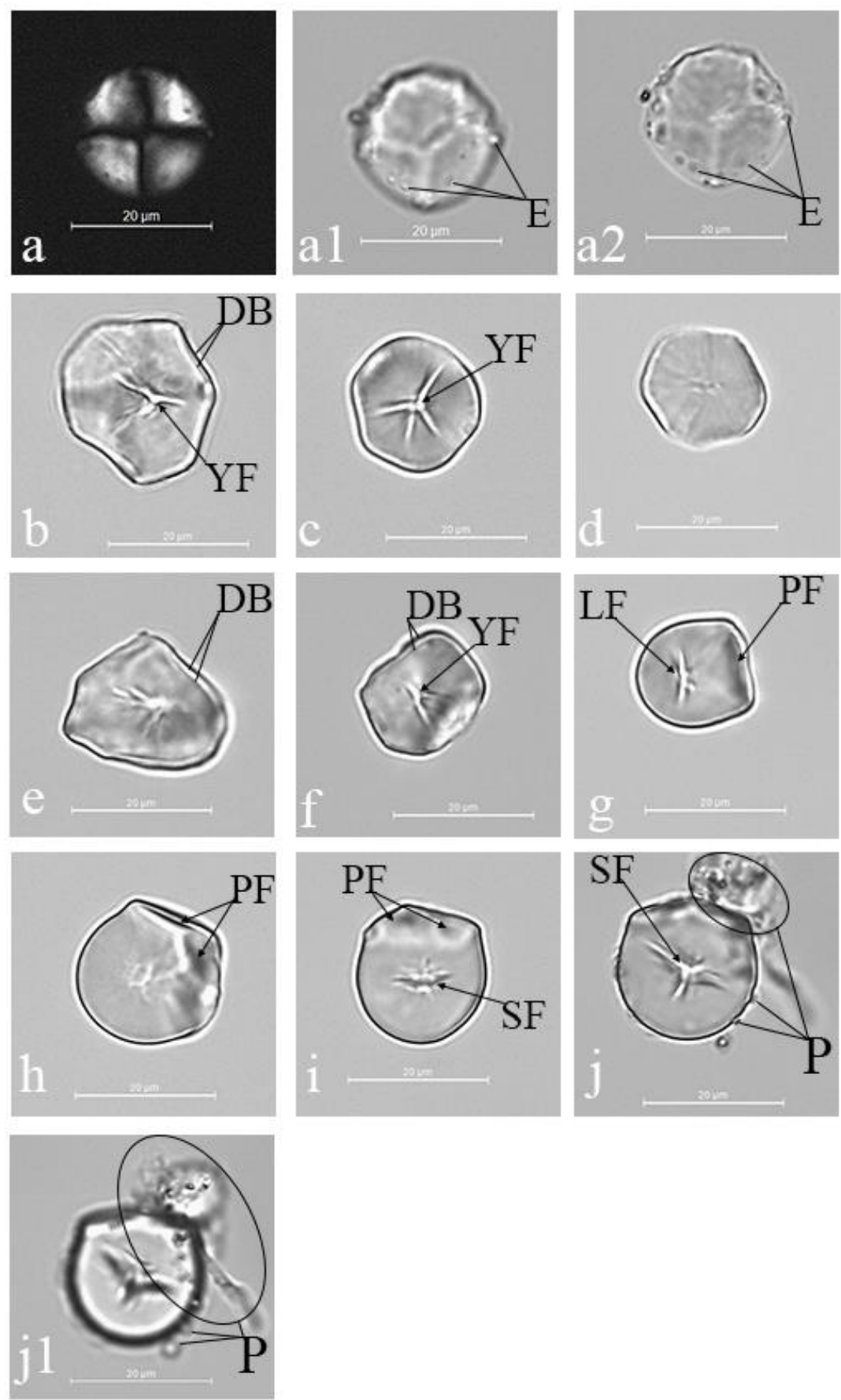

Fig. 10

Starches recovered from artifact $\mathrm{Kr} 7$.

(a) An unidentified starch with polarizing filter and dark field view. (a1) The same unidentified starch with bright field view. (a2) The same unidentified starch grain with bright field view at a different focal length highlighting the enzymatic damage. (b-f) Five securely identified maize starches with bright field view. (g-i) Three securely identified manioc starches with bright field view. (j) Manioc starch with bright field view. (j1) The same manioc starch with bright field view at a different focal length highlighting the particles on and near the surface.

Figure legend: "DB" double border; "E" enzyme degradation; "LF" lineal fissure; "P" particles; "PF" pressure facet; "SF" stellate fissure; "YF" Y-shaped fissure. 


\subsection{Artifacts $\mathrm{Krl}, \mathrm{Kr} 5, \mathrm{Kr} 6$, and $\mathrm{Kr} 8$}
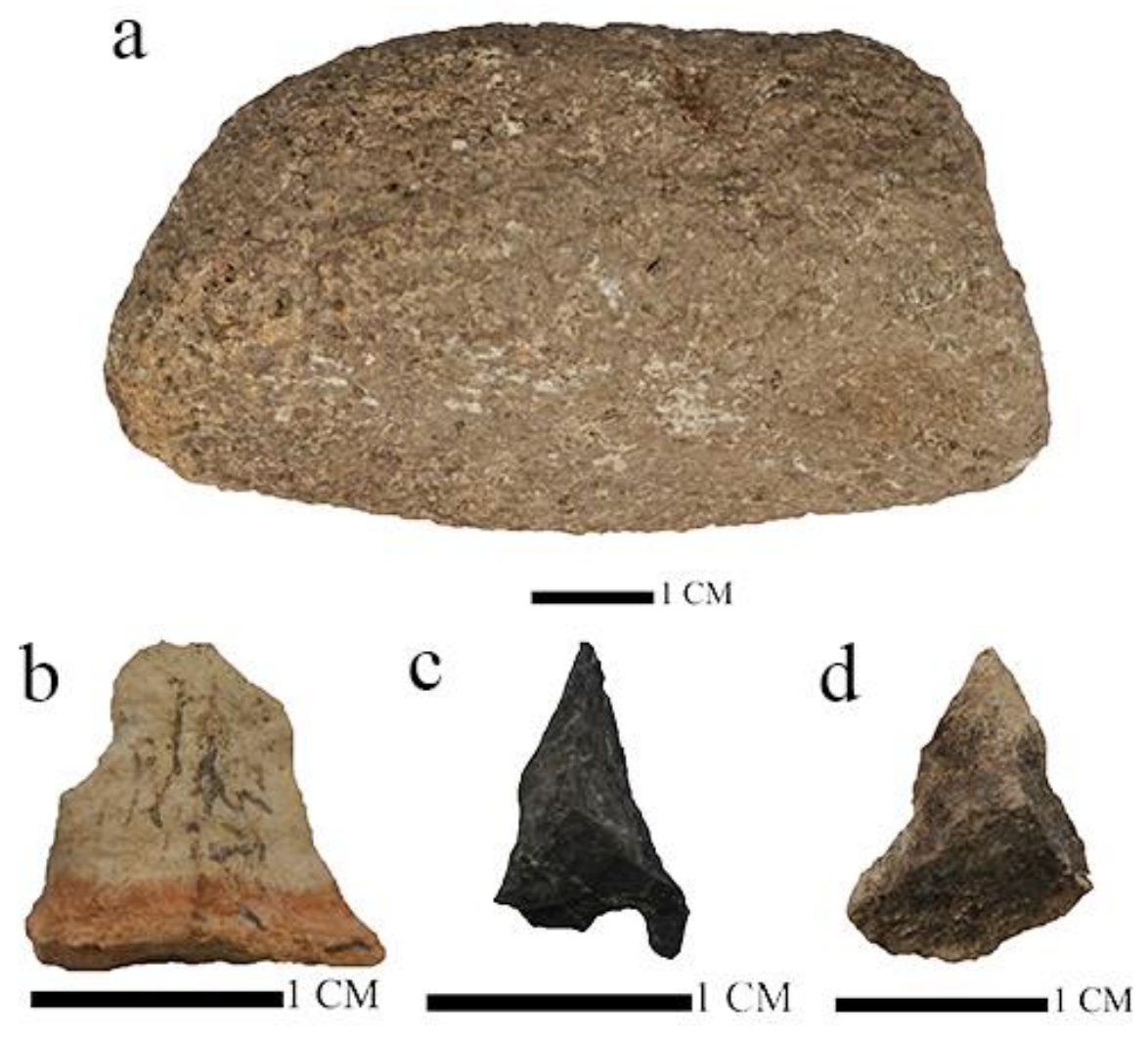

Fig. 11

Lithic artifacts sampled without recovered starches.

(a) Artifact $\mathrm{Kr} 1$

(b) Artifact Kr5

(c) Artifact Kr6

(d) Artifact Kr8

We believe these four artifacts without recovered starches to suffice for control samples mitigating concerns for post-depositional, post-excavation, pre-processing, and sample mounting contamination. Artifact Kr1 (Fig. 11a) has macroscopic evidence of smoothing on what could be presumed to have been the bottom (contact area) of a sandstone mano. Kr5 (Fig. 11b) appears to have been bifacially flaked and worked by percussion. Kr6 (Fig. 11c) does not have a flat bottom as the other micro-flaked objects do in this assemblage, maybe it was manufactured but then discarded because of this flaw. KR8 (ig. 11d) is a pyramidal shaped, small fragment of limestone. These artifacts were all processed and sampled with the exact same procedure as the previously described artifacts. However, no ancient starches were recovered, which could be from multiple reasons such as micro-taphonomic issues of preservation (Haslam, 2004, Langejans, 2010) or processing plants which produce little or no starches (Hart, 2011). Alternatively, these tools could have been used to process fish (Debert and Sherriff, 2007). Lastly, maybe these pieces of limestone were not modified by humans and thus unused. 


\section{Discussion}

The identification of cultigens is only one step in the investigation of botanical foodways, including the associated plant procurement and subsequent food processing techniques (Keegan, 2010). Foodways in the precolonial Caribbean are often described in accordance with ethnohistoric accounts (Las Casas, 1909, Sauer, 1966, Sears and Sullivan, 1978, Sturtevant, 1969). Manioc and sweet potato were considered to be the most important crops, and these were cultivated in mounded fields associated with large villages positioned to take advantage of superior soils some distance from the coast (Keegan and Hofman, 2017). In contrast, archaeological sites in The Bahamas are usually discovered to have been located on sandy soils directly on the beach (personal observations). Deposits are typically ephemeral and of small size, which suggests frequent movements.

Although coontie is listed as native to The Bahamas (Britton and Millspaugh, 1962), it currently has a restricted distribution. Today there are only six Bahama Islands with native populations of coontie: Abaco, Andros, Eleuthera, Grand Bahama, New Providence, and Long Island (Calonje, et al., 2013). The three coontie populations on Long Island have been a single panmictic population during the course of their history, but currently are considered a [critically] endangered species known as Zamia lucayana B. (common name: Long Island Coontie or Bay Rush) (Calonje, et al., 2013). Currently, Zamia lucayana B. is only found in our study area in pockets along a $6.5 \mathrm{~km}$ by $100 \mathrm{~m}$ wide strip along the dune between Turtle Cove (Hamiltons) and Clarence Town (Calonje, et al., 2013). Coontie prefers an open habitat, with wind and salt stunted vegetation (less than $50 \mathrm{~cm}$ tall) dominated by coppiced sea grape (Coccoloba uvifera (L.) (Meerow, et al., 2012). The endangered status and restricted range of Zamia Lucayana B. may be due to the absence of human disturbance and the regrowth of Palmetto woodlands along the Atlantic coastal dune on Long Island.

Berman and Pearsall (2000) reported starch grain evidence of "cf. Xanthosoma sp. (yautia) or cf. Zamia sp. on two microliths from the Three Dog site on San Salvador." Given its current distribution, if the plant producing the observed starch from that study was grown locally it is either not coontie, or the range for coontie was greater in the past, as it has been suggested by a previous study that found modern coontie populations growing wild in unexpected areas of distribution in Puerto Rico (Pagán-Jiménez and Lazcano-Lara, 2013). The recovery of possible coontie from San Salvador and the restricted range of modern coontie in The Bahamas, raise the possibility that the Lucayans transported coontie seeds or male and female plants between islands, and that coontie was cultivated or encouraged to grow by maintaining cleared areas (i.e., gardens).

In the same way that farming practices have been defined by European accounts, food processing suffers a similar bias. It is commonly assumed that meals were prepared in pottery vessels, with pepper pot used as the prime example (Berman and Pearsall, 2008, Newsom and Wing, 2004:202). Most archaeologists now recognize that griddles (flat cooking plates) were used to cook a variety of foods, but now it must be considered that a similar variety of foods were processed and cooked with tools analogous to the ones from this study (Pagán-Jiménez, 2013, Rodríguez Suárez and Pagán-Jiménez, 2008). The usual complement to pepper pot is cassava bread made from bitter (poisonous) manioc tubers processed through a sequence of procedures and then baked on a flat clay griddle (Rouse, 1992:12). Yet, potsherds are so uncommon at LN101 it would be difficult to reconstruct even one large vessel, and there is no evidence of griddles. The tools from this study were found in association with an earth oven, which is evidence for a previously unreported cooking technique in The Bahamas. Three such ovens have now been 
identified in the study area. Given the effort required to construct and use earth ovens, it is likely that a large quantity of various foodstuffs were baked at the same time (Thoms, 2008, Wandsnider, 1997).

Ethnographic accounts attest to maize being baked in its husk in earth ovens (Stevenson, 1915:76). Baking maize before further processing with a shell tool would explain the evidence for heating observed on some starch grains recovered from artifact $\mathrm{Kr} 2$. We believe the starches recovered from artifact $\mathrm{Kr} 2$ were deposited on its surface while it was being used as a food preparation tool. Two of the three starch grains tentatively identified as maize have evidence of pressure (scraping/cutting), probably generated by use of this shell tool to remove maize kernels from a cob for further processing into other foods. The evidence from artifact $\mathrm{Kr} 2$ displays starches damaged by both heat and/or pressure. Certain foods require maize kernels to be removed before further processing (Pagán-Jiménez, et al., 2016). The collated information helps us suggest that mature, but not dry, maize cobs were baked in an earth oven and then scraped with this shell tool to release the kernels to ease further processing, consumption, or storage (Mickleburgh and Pagán-Jiménez, 2012, Pagán-Jiménez, et al., 2016, Wandsnider, 1997).

The recovered starches from artifact Kr3 likely accumulated on its surface while it was used as a food preparation tool. With respect to the evidence of enzymatic degraded starches, some recipes require manioc to be fermented before being turned into a final product such as the Makushi of Guyana, South America who mix fresh manioc tubers with tubers that have fermented as part of their process to make farine (Elias, et al., 2000). In addition, many techniques to preserve foods require help from enzymatic activity (Green, 2010). Thus, the starches with enzymatic degradation damage on this tool lead us to a few plausible interpretations. Including that, at least one of the food sources was in storage, in which time it began to naturally ferment before being processed with this shell tool. This fermentation may have been intentional as in the case of the previously mentioned recipe or as a method of preservation, or alternatively, the plant organs were in storage for too long and it was time to eat them before they completely spoiled.

This research presents a limestone microlith that we interpret to have been embedded in a wooden grater board functioning as a plant-processing tool. Moving past older archaeological literature and ideas, that thought plant-processing tools were used to prepare only one type of plant (see DeBoer, 1975), this study adds to the mounting evidence providing the understanding that grater boards were not used to process only one type of plant (Berman and Pearsall, 2008, Oliver, 2001, Perry, 2002a, Perry, 2004). It is worth noting that the samples analyzed here are all limestone, whereas in the other study from The Bahamas that recovered starch grains from grater chips, they were bipolar-flaked, white chert microliths imported from the Greater Antilles (Berman and Pearsall, 2000, Perry, et al., 2007). Over 550 bipolar-flaked chert microliths were recovered at the Governor Beach site on Grand Turk in the context of beadmaking. In this case, they were identified as drill bits (Carlson, 1993) thus, not all microliths are grater chips. Because The Bahamas are devoid of igneous and metamorphic lithic sources (Keegan, 1997:45), we believe the limestone microliths are localized adaptations to the Bahamian geological environments.

\section{Conclusions}

Reconstructions of precolonial dietary subsistence strategies have been excessively dependent on zooarchaeological and ethnohistorical data with their admitted limitations. However, paleoethnobotanical studies also have inherent taphonomic biases and other limitations 
such as the spectra of plants that can be preserved, represented, and recovered. Overall, the results of this study offer a partial insight into the phytocultural dynamics of the research area. While the limited number of studied samples can be used to place the identified plants and food behaviors in chronological and geographical contexts, this data should not be used for inferring the economic or cultural significance of one plant over others at the intra- or inter-site levels. For inferring economic and cultural importance of botanical foods at different chronological and geographical scales, the study of many other artifacts or at least a larger number of samples at the site level must be analyzed and we encourage more interdisciplinary research incorporating usewear, isotopic, and macrobotanical analyses when possible (e.g., Hofman, et al., 2008).

Based on indirect inferences, manioc was believed to have been the staple root crop of indigenous Caribbean peoples, and maize wrongly considered as a minor or even high-status food source (Newsom and Wing, 2004:210, Rouse, 1992:12). Direct archaeological evidence has demonstrated that manioc use was less ubiquitous and maize use was more common that the indirect evidence led earlier scholars to believe (Berman and Pearsall, 2008, Mickleburgh and Pagán-Jiménez, 2012, Pagán-Jiménez, 2007, Pagán-Jiménez, et al., 2015). In light of these understandings, the results from this study are a significant addition to the knowledge database of precolonial botanical foodways by adding to the mounting evidence for the ubiquitous use of maize, demonstrating the use of coontie in The Bahamas, and establishing that limestone and shell tools were used to process manioc. In addition, we have highlighted potentially different processing and cooking techniques inferred from the findings of maize, previously heated before scraping the kernels, and manioc, some of them fermented before being peeled.

This research has provided novel insights, in a region with poor botanical preservation. We have demonstrated a strong case for the further study of microlithic tools from poor quality lithic sources. This research should also encourage others working on foodways in tropical regions to consider a greater diversity of plant resources, and to identify and report earth ovens. The plant remains recovered from these artifacts and the associated earth oven contexts reveal a more complex set of functions than was previously considered for precolonial Bahamian foodways, involving the processing of several starchy plants. The presence of starch grains on the surface of a microlithic tool is the first such archaeological evidence for manioc food processing with a limestone grater chip in the Caribbean. Through this research, we want to stress that paleoethnobotany and archaeometrics can contest or improve our archaeological inferences, which have been erroneously based on indirect evidence and $16^{\text {th }}$ century European descriptions.

\section{Acknowledgements}

The results of this study are part of the PhD project of Andy Ciofalo carried out at the Faculty of Archaeology, Leiden University in the context of the ERC-Synergy NEXUS1492 project grant agreement 319209. We thank both Leiden University and the Florida Museum of Natural History for providing support and lab spaces for our work. We wish to thank Nick Constantakis along with Nick and Anthony Maillus and the team of archaeological volunteers who made this work possible on Long Island, The Bahamas. We also wish to thank Sylvia from North Caicos who grows some of the best manioc. We are grateful to the Antiquities, Monuments, and Museum Corporation in The Bahamas as the agency that granted us the permission to conduct the fieldwork and the laboratory analysis. We also are grateful to Leiden Universities Caribbean Research Group for their insightful comments and suggestions. Finally, we would like to thank the two anonymous reviewers for their feedback that improved this paper. 


\section{References}

Atchison, J., Fullagar, R., 1998. Starch residues on pounding implements from Jinmium rockshelter, in: Fullagar, R. (Ed.), A Closer Look: Recent Australian Studies of Stone Tools, University of Sydney, Sydney, pp. 109-126.

Babot, M.P., 1996. Soils of the Humid Tropics, in: Richards, P.W. (Ed.), The Tropical Rain Forest: An Ecological Study, 2nd ed., Cambridge University Press, Cambridge, pp. 256272.

Babot, M.P., 2003. Starch grain damage as an indicator of food processing, in: Hart, D.M., Lynley, A.W. (Eds.), Phytolith and starch research in the Australian-Pacific-Asian regions : The state of the art Pandanus Books, Canberra, Australia.

Babot, M.P., 2006. Damage on starch from processing Andean food plants, in: Torrence, R., Barton, H. (Eds.), Ancient Starch Research, Left Coast Press Inc., Walnut Creek, California, pp. 66-67.

Barton, H., Torrence, R., 2015. Cooking up recipes for ancient starch: assessing current methodologies and looking to the future, J Archaeol Sci 56, 194-201.

Barton, H., Torrence, R., Fullagar, R., 1998. Clues to stone tool function re-examined: Comparing starch grain frequencies on used and unused obsidian artefacts, J Archaeol Sci 25, 1231-1238.

Beck, W., Torrence, R., 2006. Starch Pathways, in: Torrence, R., Barton, H. (Eds.), Ancient Starch Research, Left Coast Press Inc., Walnut Creek, California, pp. 53-74.

Berman, M.J., Gnivecki, P.L., Pateman, M.P., 2013. The Bahama archipelago, in: Keegan, W.F., Hofman, C.L., Rodríguez Ramos, R. (Eds.), The Oxford Handbook of Caribbean Archaeology., Oxford University Press, New York, pp. 264-280.

Berman, M.J., Pearsall, D.M., 2000. Plants, People, and Culture in the Prehistoric Central Bahamas: A View from the Three Dog Site, an Early Lucayan Settlement on San Salvador Island, Bahamas, Lat Am Antiq 11, 219-239.

Berman, M.J., Pearsall, D.M., 2008. At the crossroads: Starch grain and phytolith analyses in Lucayan prehistory, Lat Am Antiq 19, 181-203.

Black, S.L., Thoms, A.V., 2014. Hunter-Gatherer Earth Ovens in the Archaeological Record: Fundamental Concepts, American Antiquity 79, 204-226.

Britton, N.L., Millspaugh, C.F., 1962. The Bahama Flora, Harper, New York.

Calonje, M., Meerow, A.W., Knowles, L., Knowles, D., Griffith, M.P., Nakamura, K., FranciscoOrtega, J., 2013. Cycad biodiversity in the Bahamas Archipelago and conservation genetics of the threatened Zamia lucayana (Zamiaceae), Oryx 47, 190-198.

Carlson, L.A., 1993. Strings of command: Manufacture and utilization of shell beads among the Taíno Indians of the West Indies, Master's thesis, University of Florida, Gainesville.

Crowther, A., Haslam, M., Oakden, N., Walde, D., Mercader, J., 2014. Documenting contamination in ancient starch laboratories, J Archaeol Sci 49, 90-104.

Debert, J., Sherriff, B.L., 2007. Raspadita: a new lithic tool from the Isthmus of Rivas, Nicaragua, J Archaeol Sci 34, 1889-1901.

DeBoer, W.R., 1975. The archaeological evidence for manioc cultivation: a cautionary note, American Antiquity 40, 419-433.

Dickau, R., 2005. Resource use, crop dispersals, and the transition to agriculture in prehistoric Panama: evidence from starch grains and macroremains, Department of Anthropology, PhD. Diss., Temple University. 
Doran Jr., E., 1955. Land Forms of the Southeast Bahamas, University of Texas Publication, Austin, Texas.

Dozier, C.A., 2016. Airborne starch dispersal from stone grinding: Experimental results and implications, Journal of Archaeological Science-Reports 8, 112-115.

Elias, M., Rival, L., McKey, D., 2000. Perception and management of cassava (Manihot esculenta Crantz) diversity among Makushi Amerindians of Guyana (South America) Ethnobiology 20, 239-265.

Figueredo, A.E., 2015. Manioc dethroned and maize triumphant: interpretations on the ethnohistory and archaeology of the Bahamas with sundry notes on relations of production, Journal of Caribbean Archaeology 15, 120-134.

Fortuna, L., 1978. Analisis polinico de Sanate Abajo, Boletin del Museo del Hombre Dominicano $10,125-130$.

García-Granero, J.J., Lancelotti, C., Madella, M., 2016. A methodological approach to the study of microbotanical remains from grinding stones: a case study in northern Gujarat (India), Vegetation History and Archaeobotany 26, 43-57.

Green, J.S., 2010. Feasting with foam: Ceremonial drinks of cacao, maize, and pataxte cacao, in: Staller J.E., Carrasco M.D. (Eds.), Pre-Columbian Foodways, Springer, New York, pp. 315-343.

Hart, T.C., 2011. Evaluating the usefulness of phytoliths and starch grains found on survey artifacts, J Archaeol Sci 38, 3244-3253.

Haslam, M., 2004. The decomposition of starch grains in soils: implications for archaeological residue analyses, J Archaeol Sci 31, 1715-1734.

Henry, A.G., Hudson, H.F., Piperno, D.R., 2009. Changes in starch grain morphologies from cooking, J Archaeol Sci 36, 915-922.

Hofman, C.L., Hoogland, M.L.P., Van Gijn, A.L., 2008. Crossing the Borders New Methods and Techniques in the Study of Archaeological Materials from the Caribbean, The University of Alabama Press, Tuscaloosa.

Holst, I., Moreno, J.E., Piperno, D.R., 2007. Identification of teosinte, maize, and Tripsacum in Mesoamerica by using pollen, starch grains, and phytoliths, Proc Natl Acad Sci U S A 104, 17608-17613.

Hutschenreuther, A., Watzke, J., Schmidt, S., Budel, T., Henry, A.G., 2017. Archaeological implications of the digestion of starches by soil bacteria: Interaction among starches leads to differential preservation, Journal of Archaeological Science-Reports 15, 95-108.

Keegan, W.F., 1997. Bahamian Archaeology: Life in the Bahamas and Turks and Caicos before Columbus, Media Publishing, Nassau.

Keegan, W.F., 2010. The Archaeology of Farming Systems, in: L., H.D. (Ed.), Encyclopedia of Life Support Systems, Eolss Publishers Co. Ltd., United Kingdom, pp. 323-339.

Keegan, W.F., DeNiro, M.J., 1988. Stable carbon-and nitrogen-isotope ratios of bone collagen used to study coral-reef and terrestrial components of prehistoric Bahamian diet, American Antiquity 53, 320-336.

Keegan, W.F., Hofman, C.L., 2017. The Caribbean Before Columbus Oxford University Press, New York.

Keegan, W.F., Mitchell, S.W., 1984. The Archaeological Survey of Long Island, Bahamas: Final Report, PRIDE Foundation Publications in Caribbean Science, Providenciales, Turks \& Caicos Islands.

Keegan, W.F., Pateman, M.P., n.d. Lucayan exploitation of the windward coast of Long Island, The Bahamas, In preparation. 
Laffoon, J.E., Hoogland, M.L.P., Davies, G.R., Hofman, C.L., 2016. Human dietary assessment in the Pre-colonial Lesser Antilles: New stable isotope evidence from Lavoutte, Saint Lucia, Journal of Archaeological Science-Reports 5, 168-180.

Lammers-Keijsers, Y., 2007. Tracing Traces from Present to Past : A Functional Analysis of PreColumbian Shell and Stone Artefacts from Anse à la Gourde and Morel, Guadeloupe, FWI, PhD diss., Leiden University Press, Leiden.

Langejans, G.H.J., 2010. Remains of the day-preservation of organic micro-residues on stone tools, J Archaeol Sci 37, 971-985.

Las Casas, B., 1909. Apologetica historia de las Indias, Bailey-Ballière e Hijos Madrid.

Laurence, A.R., Thoms, A.V., Bryant, V.M., McDonough, C., 2011. Airborne Starch Granules as a Potential Contamination Source at Archaeological Sites, Journal of Ethnobiology 31, 213-232.

LeVin, A., 2017. Turks and Caicos Hurricanes.

Loy, T.H., Barton, H., 2006. Post-excavation contamination as measures for prevention, in: Torrence, R., Barton, H. (Eds.), Ancient Starch Research, Left Coast Press Inc., Walnut Creek, California, pp. 165-167.

Loy, T.H., Spriggs, M., Wickler, S., 1992. Direct Evidence for Human Use of Plants 28,000 Years Ago - Starch Residues on Stone Artifacts from the Northern Solomon-Islands, Antiquity 66, 898-912.

Ma, Z.K., Zhang, C., Li, Q., Perry, L.D., Yang, X.Y., 2017. Understanding the Possible Contamination of Ancient Starch Residues by Adjacent Sediments and Modern Plants in Northern China, Sustainability 9, 752.

Meerow, A.W., Francisco-Ortega, J., Calonje, M., Griffith, M.P., Ayala-Silva, T., Stevenson, D.W., Nakamura, K., 2012. Zamia (Cycadales: Zamiaceae) on Puerto Rico: asymmetric genetic differentiation and the hypothesis of multiple introductions, Am J Bot 99, 18281839.

Mercader, J., Abtosway, M., Baquedano, E., Bird, R.W., Diez-Martin, F., Dominguez-Rodrigo, M., Favreau, J., Itambu, M., Lee, P., Mabulla, A., Patalano, R., Perez-Gonzalez, A., Santonja, M., Tucker, L., Walde, D., 2017. Starch contamination landscapes in field archaeology: Olduvai Gorge, Tanzania, Boreas 46, 918-934.

Mercader, J., Bundala, M., Collins, M.J., Copeland, L., Crowther, A., Henry, A., Itambu, M., Larter, S., Longo, L., Patalano, R., 2018. Exaggerated expectations in ancient starch research and the need for best practices and authenticity criteria.

Messner, T.C., 2011. Acorns and Bitter roots: starch grain research in the prehistoric Eastern woodlands, University of Alabama Press, Tuscaloosa.

Mickleburgh, H.L., Pagán-Jiménez, J.R., 2012. New insights into the consumption of maize and other food plants in the pre-Columbian Caribbean from starch grains trapped in human dental calculus, J Archaeol Sci 39, 2468-2478.

Mills, C., 2009. A history of the Turks \& Caicos Islands, Oxford, Macmillan.

Newsom, L.A., 1993. Native West Indian Plant Use, Department of Anthropology, PhD diss., University of Florida, Gainesville, University Microfilms, Ann Arbor.

Newsom, L.A., Wing, E.S., 2004. On land and sea: Native American uses of biological resources in the West Indies, University of Alabama Press, Tuscaloosa.

Oliver, J.R., 2001. The archaeology of forest foraging and agricultural production in Amazonia, in: McEwan, C., Neves, E.G., Barreto, C. (Eds.), The Unknown Amazon: Culture in Nature in Ancient Brazil, British Museum Press, London, pp. 50-85. 
Pagán-Jiménez, J.R., 2007. De antiguos pueblos y culturas botánicas en el Puerto Rico indígena: el archipiélago borincano y la llegada de los primeros pobladores agroceramistas, Paris Monographs in American Archaeology Series 18, British Archaeological Reports International Series 1687, Archaeopress, Oxford.

Pagán-Jiménez, J.R., 2009. Nuevas perspectivas sobre las culturas botánicas precolombinas de Puerto Rico: implicaciones del estudio de almidones en herramientas líticas, cerámicas y de concha, Cuba Arqueológica 2, 7-23.

Pagán-Jiménez, J.R., 2011. Assessing Ethnobotanical Dynamics at C.E.-11 and C.E.-33 through Analysis of Starch Grains, Plant Processing, and Cooking Artifacts, in: Carlson, L.A., Torres, J. (Eds.), Phase III Data Recovery Investigations at Three Prehistoric Archaeological Sites (CE.-11, CE.-32, and CE.-33), Municipality of Ceiba, Naval Activity Puerto Rico. Southeastern Archaeological Research, Florida, Copy available at the Puerto Rico State Historic Preservation Office, San Juan, pp. 325-375.

Pagán-Jiménez, J.R., 2013. Human-Plant Dynamics in the Precolonial Antilles, in: Keegan, W.F., Hofman, C.L., Rodríguez Ramos, R. (Eds.), The Oxford Handbook of Caribbean Archaeology, Oxford University Press, New York, pp. 391-406.

Pagán-Jiménez, J.R., 2015a. Almidones. Guía de Material Comparativo Moderno del Ecuador para los Estudios Paleoetnobotánicos en el Neotrópico Aspha Ediciones, Buenos Aires.

Pagán-Jiménez, J.R., 2015b. Evaluando algunos mecanismos de conservación/degradación en almidones modernos por medio de ensayos y experimentos controlados que replican ciertas formas antiguas de procesamiento y cocción de órganos almidonosos. Elaboración de dos tipos de chicha de maíz: chicha fermentada con saliva y otra con levadura, Instituto Nacional de Patrimonio Cultural, Quito, p. 17.

Pagán-Jiménez, J.R., Guachamín-Tello, A.M., Romero-Bastidas, M.E., Constantine-Castro, A.R., 2016. Late ninth millennium B.P. use of Zea mays L. at Cubilán area, highland Ecuador, revealed by ancient starches, Quatern Int 404, 137-155.

Pagán-Jiménez, J.R., Guachamín-Tello, A.M., Romero-Bastidas, M.E., Vásquez-Ponce, P.X., 2017. Cocción experimental de tortillas de casabe (Manihot esculenta Crantz) y de camote (Ipomoea batatas [L.] Lam.) en planchas de barro: evaluando sus efectos en la morfometría de los almidones desde una perspectiva paleoetnobotánica, Americae 2, 27 44.

Pagán-Jiménez, J.R., Lazcano-Lara, J.C., 2013. Toponymic Data Helps to Reveal the Occurrence of Previously Unknown Populations of Wild Zamia pumila L. on Volcanic Substrates in South Central Puerto Rico, Ethnobiology Letters 4, 52-58.

Pagán-Jiménez, J.R., Oliver, J.R., 2008. Starch Residues on Lithic Artifacts from Two Contrasting Contexts in Northwestern Puerto Rico: Los Muertos Cave and Vega de Nelo Vargas, in: Hofman, C.L., Hoogland, M.L.P., Van Gijn, A.L. (Eds.), Crossing the Borders: New Methods and Techniques in the Study of Archaeological Materials from the Caribbean, University of Alabama Press, Tuscaloosa, pp. 137-158.

Pagán-Jiménez, J.R., Rodríguez Ramos, R., Reid, B.A., van den Bel, M., Hofman, C.L., 2015. Early dispersals of maize and other food plants into the Southern Caribbean and Northeastern South America, Quat. Sci. Rev. 123, 231-246.

Pearsall, D.M., Chandler-Ezell, K., Zeidler, J.A., 2004. Maize in ancient Ecuador: results of residue analysis of stone tools from the Real Alto site, J Archaeol Sci 31, 423-442.

Pereira, B.L.B., Leonel, M., 2014. Resistant starch in cassava products, Food Science and Technology 34, 298-302. 
Perry, L., 2002a. Starch analyses reveal multiple functions of quartz "Manioc" grater flakes from the Orinoco Basin, Venezuela, Interciencia 27, 635-639.

Perry, L., 2002b. Starch Granule Size and the Domestication of Manioc (Manihot Esculenta) and Sweet Potato (Ipomoea Batatas)1, Econ Bot 56, 335-349.

Perry, L., 2004. Starch analyses reveal the relationship between tool type and function: an example from the Orinoco valley of Venezuela, J Archaeol Sci 31, 1069-1081.

Perry, L., Dickau, R., Zarrillo, S., Holst, I., Pearsall, D.M., Piperno, D.R., Berman, M.J., Cooke, R.G., Rademaker, K., Ranere, A.J., Raymond, J.S., Sandweiss, D.H., Scaramelli, F., Tarble, K., Zeidler, J.A., 2007. Starch fossils and the domestication and dispersal of chili peppers (Capsicum spp. L.) in the Americas, Science 315, 986-988.

Pestle, W.J., Laffoon, J.E., 2018. Quantitative paleodietary reconstruction with complex foodwebs: An isotopic case study from the Caribbean, Journal of Archaeological ScienceReports 17, 393-403.

Piperno, D.R., 2006. Identifying manioc (Manihot esculenta Crantz) and other crops in preColumbian tropical America through starch grain analysis: A case study from central Panama, in: M.A., Z., D.G., B., E., E., B.D., S. (Eds.), Documenting domestication: new genetic and archaeological paradigms, University of California Press, Berkeley, pp. 4667.

Piperno, D.R., Holst, I., 1998. The presence of starch grains on prehistoric stone tools from the humid neotropics: Indications of early tuber use and agriculture in Panama, J Archaeol Sci 25, 765-776.

Piperno, D.R., Ranere, A.J., Holst, I., Iriarte, J., Dickau, R., 2009. Starch grain and phytolith evidence for early ninth millennium B.P. maize from the Central Balsas River Valley, Mexico, Proc Natl Acad Sci U S A 106, 5019-5024.

Reichert, E.T., 1913. The differentiation and specificity of starches in relation to genera, species, etc: stereochemistry applied to protoplasmic processes and products, and as a strictly scientific basis for the classification of plants and animals, Carnegie institution of Washington, Washington, D. C.

Rodríguez Suárez, R., Pagán-Jiménez, J.R., 2008. The Burén in precolonial Cuban archaeology: New information regarding the use of plants and ceramic griddles during the Late Ceramic Age of Eastern Cuba gathered through starch analysis, in: Hofman, C.L., Hoogland, M.L.P., Van Gijn, A.L. (Eds.), Crossing the Borders, New Methods and Techniques in the Study of Archaeological Materials from the Caribbean, The University of Alabama Press, Tuscaloosa, pp. 159-169.

Rouse, I., 1992. The Tainos, Rise and decline of the people who greeted Columbus, Yale University Press, New Haven.

Sauer, C.O., 1966. The Early Spanish Main, University of California Press., Berkley and Los Angeles, California.

Sears, W.H., Sullivan, S.O., 1978. Bahamas Prehistory, American Antiquity 43, 3-25.

Stevenson, M.C., 1915. Ethnobotany of the Zuñi Indians, US Government Printing Office, Washington, DC.

Sturtevant, W.C., 1969. History and ethnography of some West Indian starches, in: Ucko, P.J., Dimbleby, G.W. (Eds.), The Domestication and Exploitation of Plants and Animals, Gerald Duckworth \& Co. Ltd., London, pp. 177-199.

Tabío, E.E., Rey, E., 1985. Prehistoria de Cuba, Editorial Ciencias Sociales, La Habana.

Therin, M., 1998. The movement of starch grains in sediments, in: Fullagar, R. (Ed.), A Closer Look: Recent Australian Studies of Stone Tools, Sydney University, Sydney, pp. 61-72. 
Thoms, A.V., 2008. The fire stones carry: Ethnographic records and archaeological expectations for hot-rock cookery in western North America, Journal of Anthropological Archaeology 27, 443-460.

Torrence, R., 2006. Starch and archaeology, in: Torrence, R., Barton, H. (Eds.), Ancient starch research, Left Coast Press Inc., Walnut Creek, pp. 17-33.

Ugent, D., Pozorski, S., Pozorski, T., 1986. Archaeological Manioc (Manihot) from Coastal Peru, Econ Bot 40, 78-102.

van den Bel, M., Knippenberg, S., Pagán Jiménez, J.R., 2018. From cooking pits to cooking pots. Changing modes of food processing during the Late Archaic Age in French Guiana, in: Reid, B.A. (Ed.), The Archaeology of Caribbean and Circum-Caribbean Farmers $(6000$ BC-AD 1500), Routledge, London and New York, pp. 391-418.

Van Gijn, A.L., Lammers- Keijsers, Y., Briels, I., 2008. Tool Use and Technological Choices: An Integral Approach toward Functional Analysis of Caribbean Tool Assemblages, in: Hofman, C.L., Hoogland, M.L.P., Van Gijn, A.L. (Eds.), Crossing the Borders: New Methods and Techniques in the Study of Archaeology Materials from the Caribbean, University of Alabama Press, Tuscaloosa,, pp. 101-114.

Veloz Maggiolo, M., 1992. Notas sobre la Zamia en la Prehistoria del Caribe, Revista de Arqueología Americana 6, 125-138.

Veloz Maggiolo, M., Zanin, D., 1999. Historia, arte y cultura en las Antillas precolombinas, Editora Universitaria-UASD, Santo Domingo.

Walker, J., Wilk, R., Clark, J.E., 1989. The manufacture and use-wear characteristics of ethnographic, replicated, and archaeological manioc grater board teeth, in: M.G., G., E., C.J. (Eds.), La obsidiana en Mesoamérica, Instituto Nacional de Antropología e Historia, Mexico City, pp. 459-463.

Wandsnider, L., 1997. The roasted and the boiled: Food composition and heat treatment with special emphasis on pit-hearth cooking, Journal of Anthropological Archaeology 16, 1-48. 